\title{
INDUSTRIMINNEN UNDER HUNDRA ÅR
}

\author{
Marie Nisser
}

Arbetets byggnader har under några årtionden betraktats som legitima vårdobjekt. Inom svensk kulturmiljövård är industriminnen föremål för omfattande insatser. Industribyggnader återanvänds, industrins bostadsområden rustas upp och industrilandskap är forremål for nationella och regionala bevarandeprogram. Industriminnesforskning har vunnit status som akademisk disciplin.

Den breda uppslutningen kring industriminnen har vuxit fram under de senaste decennierna. I slutet av 1960-talet var varken den offentliga kulturminnesvården eller arbetsgivare- och arbetstagarorganisationer inställda på att bevara fabriker, renovera arbetarbostäder eller vårda sammanhängande industrimiljöer annat än $\mathrm{i}$ undantagsfall. Sverige var knappast unikt i detta avseende. Även på andra håll i världen har det industriella arvet vunnit status som kulturarv först under de senaste tre årtiondena.

I Sverige kan vi trots detta tala om industriminnesvård $\mathrm{i}$ ett snart hundraårigt perspektiv. I andra sammanhang har jag försökt att karakterisera de tidigaste incitamenten till en dokumentation och ett bevarande av industriminnen. Här skall jag begränsa mig till att mer översiktligt försöka beskriva denna utveckling. Man skulle kunna beskriva industriminnesvårdens begynnelse och dess fortsatta etablering $\mathrm{i}$ ett antal faser.

\section{BANBRYTARNAS TID}

Den första fasen kan karakteriseras som banbrytarnas tid då verksamheten legitimerades inom samhällets övre skikt. Denna period tog sin början åren kring sekelskiftet 1900 för att under 1920-talet ändra karaktär och bli alltmer institutionaliserad.

De första initiativen för att slå vakt om det industriella arvet var framförallt knutna till en bransch, den sektor som under århundraden hade dominerat det svenska näringslivet - bergshanteringen.

Bergslagen befann sig under senare hälften av 1800-talet mitt inne i ett genomgripande omvandlingsskede. Bruksnäringen ömsade skal. Hundratals hyttor, hamrar och bruk lades ned, utmanövrerade av de livskraftiga, tekniskt väl utrustade och marknadsorienterade storföretagen. Upplösningen av den gamla bergsmanskulturen var en följd av samhällets omdaning till en modern industrination. Detta skede av förändringar sammanföll under 1800talets sista årtionde med den våg av natio- 
74 nell romantik som svepte över landet. Nationalromantikerna fann inspiration även i bergshanteringens miljöer, inte minst i brukspatronernas och smedernas värld.

I dikten, konsten och arkitekturen sökte man sig tillbaka till bergslagsbygderna till trakter, rika på minnen och sägenomspunna miljöer. Diktare och författare som Gustaf Fröding, Dan Andersson och Selma Lagerlöf hämtade sina motiv från hammarsmedjorna, kolmilorna och bruken. Ferdinand Boberg sökte upp sina gamla barndomstrakter i Bergslagen för ett brett upplagt projekt att i kolteckningar och akvareller föreviga en bortdöende kultur. John Åkerlund var en av flere arkitekter som i den klassiska bruksarkitekturen fann förebilder för egna uppdrag i Bergslagens industriorter. Alla bidrog de till att understryka de poetiska och estetiska kvaliteterna i brukshanteringens miljöer och att vidga intresset för bergshanteringen till grupper inom samhället som stod utanför de konstnärliga kretsarna.

Ett karakteristiskt drag i den tidiga industriminnesvårdens historia i Sverige är dess elitistiska inslag. Det var det ledande skiktet inom bergshantering, järn- och stålindustri som gick i spetsen för bevarandeinsatserna. Det var de stora företagen som svarade för finansieringen av vården av de anläggningar de hade i sin ägo. Många bruksledare hade vuxit upp i de bruk där de kom att tillbringa sitt yrkesverksamma liv. Syftet med den bergshistoriska minnesvården handlade i första hand om ett ansvarstagande för historiska traditioner. En folklig förankring eftersträvades knappast. Ej heller var det primära syftet att skildra de människor som arbetat i hyttorna och hamrarna.

Bakom aktionerna med målsättningen att rädda bergshanteringens kultur åt eftervärlden stod flera industrimän $i$ det tidiga 1900-talet. De kan följaktligen karakteriseras som banbrytarna på industriminnesvårdens område. Här faller det ur ramen att beskriva deras insatser mer ingående, men några av dem skall nämnas. En av pionjärerna var Carl Sablin, tekniker och företagsledare. Vid sidan av sin dagliga gärning som industriledare ägnade han sig åt svensk bergshistoria. Han var också en energisk samlare och producerade sig flitigt $\mathrm{i}$ skrift. Han såg Bergslagen med teknikerns ögon, men fann snart att den industri "som jag valt till levnadsyrke, ägde en rik och mycket fängslande äldre historia.» Under sin tid som gruvingenjör och disponentassistent i Stora Kopparbergs Bergslags Aktiebolag började han ordna företagets samlingar i Falun. Han byggde upp ett bruksmuseum i Laxå bruk som invigdes 1901. Hans stora samling av gravyrer och teckningar donerades till Jernkontoret, där de kom att bilda grunden för den förnämliga bruksbildsamlingen. Hans bergshistoriska arkiv skänktes sedermera till Tekniska Museet, där Sahlin också var ledamot av styrelsen.

Generalkonsul Axel Ax:son Johnson gick i spetsen för att bevara bergshistoriska miljöer i Johnsonkoncernens ägo. Däribland kan nämnas Engelsbergs bruk, Sala silvergruva och Pershyttan.

Gösta Wesslén var skogschef för Uddeholms AB åren 1923-1945. Hyttorna $\mathrm{i}$ Motjärnshyttan, Gammelkroppa och Brattfors är tre av de anläggningar, som på hans tillskyndan kommit att bevaras.

Dessa och likartade insatser var i första hand styrda av ett personligt intresse och ansvarstagande. Andra tog intryck härav och många av de större bruksföretagens sty- 
relser fattade beslut om att slå vakt om byggnader och anläggningar i det egna företagets ägo. Det tycktes inte finnas någon motsättning när det gällde att hävda det industriella arvet för ändamål som syftade att föra näringen framåt. Sverige hade under århundraden varit en av de främsa järntillverkarna på exportmarknaden och svenskt stångjärn hade vunnit internationell ryktbarhet för sina goda kvalitetsegenskaper. De bevarade anläggningarna blev symboler för en månghundraårig kunskapsutveckling. Svenskt yrkeskunnande inom bergsmannanäringen vilade på erfarenheter som gått $\mathrm{i}$ arv under flera generationer. I hyttor och hamrar kunde man visa på en tradition som vidmakthållits och vidareutvecklats under seklernas lopp.

Till de tidigaste insatserna hör Örebro läns museums förvärv 1910 av Siggebohyttans bergsmansgård, en av landets ståtligaste bergsmansanläggningar från slutet av 1700-talet. Carl Sahlin var en av initiativtagarna till denna räddningsaktion. Sedan 1927 har gården också varit tillgänglig som museum.

Ett stort antal av de hyttor och hamrar som togs ur drift fick stå kvar med utrustningen intakt bevarad. Kanske hoppades man på bättre tider med återupptagen verksamhet. De avlägset belägna anläggningarna djupt inne i Bergslagens skogar var knappast eftertraktade för moderna industrisatsningar. Vallonsmedjan i Österbybruk i Uppsala län togs ur drift 1906 men fick stå kvar, så ock Löa bergsmanshytta i Örebro län, som blåstes ned för alltid 1907. Hyttan i Engelsbergs bruk i Väștmanlands län togs ur drift 1919. Några år dessförinnan hade generalkonsul Axel Ax:son Johnson inträtt som ägare till bruket och han beslöt vid hyttans ned- läggning att hela bruksmiljön skulle bevaras. Hyttan, stångjärnssmedjan och övriga bruksbyggnader underhölls av ägaren under de år som följde.

\section{MUSEIGRUNDANDETS ARTIONDE}

Nästa etapp inleddes under 1920-talet och skulle kunna karakteriseras som museigrundandets tid. Fortfarandet var det de ledande kretsarna inom svenskt näringsliv som var de drivande krafterna. Till de viktigare händelserna hörde i kronologisk ordning invigningen av Stora Kopparbergs Bergslags Aktiebolags museum 1922, jubileumsutställningen i Göteborg 1923 och stiftarorganisationernas beslut om att grunda ett tekniskt museum i Stockholm 1924. Samma år fattades även ett beslut om att samla in medel för ett gruvmuseum i Ludvika.

Med invigningen av Stora Kopparbergs museum i Falun skapades ett företagsmuseum som skulle lyfta fram landets äldsta i drift varande industriföretag och dess glansfulla historia. Samlingarna utställdes i Stora Gruvstugan uppförd åren 1771-85, vid randen av Storgruvestöten. Syftet med museet var primärt att belysa teknik och arbetsorganisation vid Falu koppargruva och kopparverk och sekundärt verksamheten vid de många järnverken i företagets ägo. Polhem "den svenska teknikens fader» blev också en central gestalt i gruvans utställning. Hans mer än 30-åriga verksamhet vid Falu gruva (1693-1730-talet) var ett skede av betydelsefull teknikutveckling och reorganisation av gruvdriften i Falun. Gruvarbetarna och deras historia liksom arbetsförhållanden vid gruvan spelade en underordnad roll i museets utställning. Stora Kopparbergs Bergslags muse- 
76 um kom att bli en förebild för andra företagsmuseer som grundades åren därefter, såväl inom som utom landet. I första hand blev målsättningen för sådana företagsmuseer att visa den industri- och teknikhistoriska utvecklingen. Miljön skulle helst vara autentisk som i Falun, där koppargruvan var den naturliga utgångspunkten för det som visades i museet.

En viktig händelse var Jubileumsutställningen i Göteborg 1923. Dess syfte var att förmedla ett brett kulturhistoriskt perspektiv bakåt i tiden. Den s.k. andra sektionen bestod av de hantverks- och industrihistoriska avdelningarna som skulle belysa «äldre nu mestadels övergivna tekniska hjälpmedel och arbetsmetoder, som använts inom industrin, mest dock under 1800-talet, men i vissa fall ännu tidigare».

Utställningen fick också stor betydelse för att sprida intresset för industrihistorisk vård och dokumentation till fler branscher än bergshanteringen. Den har karakteriserats som en generalmönstring av svenskt arbete och liv. Förutom föremålsinsamling var även filmupptagningar av svensk industri ett viktigt led i det förberedande arbetet med utställningen. Detta initiativ ledde också till att flera industrianläggningar med ålderdomliga framställningsmetoder då, men även under de följande åren, kom att dokumenteras på film. Dit hör t.ex. filmerna om Korså bruk och om Ösjöfors handpappersbruk. Idag är de ovärderliga dokument om äldre arbetsmetoder och arbetsmiljöer.

År 1924 grundades Tekniska museet i Stockholm. Torsten Althin hade varit utställningskommissarie vid Göteborgsutställningen och han blev nu utsedd att bygga upp museets samlingar. Han började från ett noll-läge. Det fanns varken sam- lingar eller museilokaler. De ekonomiska anslagen var begränsade. Torsten Althins entusiasm och förmåga att vinna människor för ett angeläget syfte visade sig dock vara oskattbara resurser i insamlingsarbetet. Althin reste runt i landet och arbetade sig igenom företagsarkiv, ritningssamlingar och maskinell utrustning i verkstäder och industrihallar. Outtröttlig verkade han som propagandist för det blivande museet. Han var ständigt ute på föreläsningsturnéer och skrev artiklar i dagspress och tidskrifter. Hans populärvetenskapliga föreläsningar hade ambitionen att väcka allmänhetens intresse för vetenskapens och teknikens historia - och i förlängningen härav också för det blivande museet. Men den främsta målsättningen med detta museum var att ge legitimitet åt en växande yrkeskår av tekniker. Althin formulerade målsättningen i Industritidningen Norden 1925:

Teknikens historia $\mathrm{i}$ vårt land och betydelsen av den svenska industrien kräva, att landets nu levande ingenjörer och industrimän skapar åt sina föregångare, åt sig själva och åt sina efterkommande sin egen museala institution, som för dem själva kommer att vara en erinran om tidigare vunna resultat och en sporre till fortsatt framgångsrikt arbete och som för alla andra samhällsdelar kan visa, vad de svenska teknikerna uträttat och nu äro sysselsatta med.

Tekniska museet kom också att bli de svenska ingenjörernas eget museum. De var initiativtagarna och har också i fortsättningen genom sina stiftarorganisationer haft stort inflytande över museets insamlings- och utställningsverksamhet.

Torsten Althin byggde även upp ett internationellt kontaktnät. Han var angelägen om att hålla sig underrättad om byggnadsplaner för de utländska tekniska museerna 
och de senaste idéerna på utställningsteknikens område. Deutsches Museum i München, invigt 1925, framstod som den främsta förebilden. När Tekniska Museet invigdes i sina nyuppförda lokaler på Djurgården i Stockholm 1936 var det också en kopia i liten skala av Deutsches Museum. Men det tyska museet hade ambitionen att skildra den internationella utvecklingen av teknik, medan Tekniska Museet i Stockholm blev ett museum för den svenska industrin. Svante Lindqvist, professor i teknik- och vetenskapshistoria vid KTH, har skildrat museets tillkomst och framhållit att museets historieskrivning var en «spegelbild av nuet».

Ludvika gruvmuseum är det första industrihistoriska friluftsmuseet i sitt slag i världen. Det tillkom på initiativ av Ludvika Hembygdsförening bildad 1920, betecknande nog med hembygdsforskaren och författaren Karl-Erik Forsslund som ordförande. Karl-Erik Forsslund hade själv hämtat mycket av sin inspiration på Skansen. Med den gamla bergsmanskulturen kände han en samhörighet. Vid sjön Väsman utanför Ludvika hade han skapat sitt hem i en gammal bergsmansgård för att förverkliз̧а sina drömmar om ett liv där natur och antlig kultur ingått en lycklig förening.

År 1924 stiftade Ludvika Hembygdsörening en gruvfond med syfte att efter land bygga upp ett museum. Ett markImråde i Ludvika förvärvades och under le följande åren insamlades byggnader, naskiner och bruksföremål från gamla ruv- och hyttplatser i Ludvika, Grangäre, Norrbärke och Söderbärke socknar. Ar 938 kunde Ludvika gruvmuseum högtidgen invigas. Byggnader och äldre gruvtrustning hade flyttats till museiområdet sm därför inte speglade någon reell gruviiljö. Återigen var det de historiska ste- gen i gruvtekniken som i första hand illustrerades.

\section{INDUSTRIARKEOLOGINS GENOM- BROTT I STORBRITANNIEN}

En tredje fas inleddes med att allt fler länder började intressera sig för arbetets miljöer under 1960-talet. Händelseförloppet i Storbritannien tilldrog sig uppmärksamhet. Där hade Michael Rix, vid Birminghams universitets Extra Mural Department, redan i The Amateur Historian 1955 hävdat att det industriella arvet var lika viktigt som någon annan form av mänsklig aktivitet. Ångmaskiner, lokomotiv, de första järnkonstruktionerna i byggnader, de tidiga akvedukterna och broarna av gjutjärn, järnvägar och mycket annat representerade tillsammans med fabriker och arbetarbostäder enligt Rix a fascinating, interlocking field of study, whole tracts of which are virtually unexplored.

Den första konferensen om industrins monument organiserades av Council for British Archaeology 1959 och den första boken inom ämnesområdet författad av Kenneth Hudson, Industrial Archaeology an introduction, publicerades 1963. Mer än någon annan har Kenneth Hudson bidragit till att popularisera Industrial Archaeology både i sitt eget land och internationellt.

Verksamheten blev alltså känd som Industrial Archaeology, ett begrepp som utsattes för mycken kritik. Ämnet liknades vid en bastard an impossible mongrel, the ugly offspring of two parents who should never have been allowed to breed. Begreppet industri stod för en utveckling under drygt hundra år, medan arkeologi ansågs handla om mer avlägsna tidsperioder. För många kritiker framstod det som obegrip- 
78 ligt att två så skilda verksamheter skulle kunna förenas.

Det handlade ofta om industriarkeologi i ordets verkliga bemärkelse under de första åren i Storbritannien. Intresset koncentrerades kring objekt, byggnader och miljöer som kunde förknippas med den industriella revolutionen - Englands storartade genombrott och dess framväxt som ledande industrination.

Paradoxalt nog var det $\mathrm{i}$ industrikrisernas spår som intresset ökade för industrins och teknikens historia. Det kanske inte var så märkligt. I tider av otrygghet blickar man gärna tillbaka. Man vill finna sin identitet i tillvaron och söka sin samhörighet med det som en gång var. Nostalgiska känslor fanns också med i bilden. Det var inte krisår, avveckling och nedläggning som i första hand hörde till teknik- och industrihistorikernas främsta arbetsfält utan de tekniska landvinningarna, uppbyggnadsskeden och produktionsökning.

Därför var det inte heller övergivna industriområden från 1900-talets senaste årtionden och förslummade arbetarbostäder som tidigast hörde till industriarkeologernas mest omhuldade studieobjekt, allra minst i Storbritannien och U.S.A., utan de ståtliga och odiskutabelt betydelsefulla monumenten från industrialismens genombrottsår - hyttorna, ångmaskinerna, de tidiga tekniska pionjärverken o.s.v. Industriarkeologerna försökte bygga upp kunskapen om en tid av framåtskridande, en period då England innehaft den tekniska och industriella ledningen. Ungefär samtidigt var också historikerna sysselsatta med att diskutera industrialismens genombrott och Englands ledande roll i denna utveckling.

Två grupper kom snart att engagera sig i den industriarkeologiska verksamheten i
Storbritannien - amatörerna och akademikerna, vilket snart ledde till konflikter om syften, metoder och restaureringsteorier. Omkring 1970 tycktes de två grupperna dock ha funnit var sin nisch. Amatörerna koncentrerade sig på fältarbeten och lokala bevarandeinsatser. Akademikerna började se sig själva som förmedlare av de stora perspektiven kring industrins utveckling och som uttolkare av ett hittills obeaktat källmaterial: det industriella arvet i fysisk bemärkelse.

Bland industriarkeologerna kunde man snart också urskilja två huvudlinjer. Den ena linjens företrädare såg kunskapen om teknik och industri förmedlad genom föremålen som det primära, men också visualiserad i byggnader, miljöer och landskap som tidigare inte hade betraktats som arkitektur eller kultur. Den andra linjens förespråkare framhöll den sociala dimensionen i arbetsmiljöernas historia. Kenneth Hudson gav industriarkeologin sin uttolkning med följande ord:

To regard industrial remains as dead objects, mere buildings and machinery, is to miss most of the point of industrial archaeology. The objects are there to stimulate one's historical awareness, and the more one knows about social conditions at the time, the greater and more rewarding that stimulus is likely to be.

Efter hand har dessa två ben på vilka den tidiga industriarkeologin vilade kommit att betraktas som ämnesområdets två huvudkomponenter.

\section{DET TREDJE STEGET I SVERIGE - ETABLERING OCH ACCEPTANS}

1970-talet kan i Sverige betecknas som en period av uppvaknande, en allt större 
medvetenhet och en ökad insikt om att det industriella arvet måste ägnas större utrymme inom kulturminnesvården. År 1968 hölls en sammankomst på Tekniska Museet i Stockholm i syfte att försöka få igång en frivillig inventeringsverksamhet av arbetets byggnader och miljöer, och Kenneth Hudson var där. Det visade sig emellertid att det ännu skulle dröja några år innan intresset för arbetsplatserna vann en bredare uppslutning. Här var förhållandena således annorlunda än i Storbritannien. Det gick trögt att få igång en amatöraktivitet kring dokumentation och vård av industriminnen i slutet av 1960talet. Samma år som diskussionen på Tekniska Museet ägde rum, ordnades en utställning i Värmlands museum om industrins strukturomvandling och detta var också temat för museets årsskrift 1968.

Mot slutet av 1960-talet togs flera industribyggnader upp i det åtgärdsprogram som handlade om byggnadsrestaurering med medel från Arbetsmarknadsstyrelsen (AMS).

Diskussionen om kulturminnesvårdens ansvarsområde och urval av skyddsvärda byggnader och miljöer började föras utifrån nya infallsvinklar än tidigare. 1974 års kulturpolitiska beslut blev en kraftig markering av det nya synsätt som vunnit allt större förankring också politiskt. Kulturminnesvården fick här en tydligare roll som medaktör i samhällsplaneringen med uppgift att där bevaka kulturintressen i den fysiska miljön och aktivt planera för ett säkerställande av kulturmiljöer. Målsättningen skulle vara att ge en i möjligaste mån rättvis bild av det historiska förlopp som hade lett fram till dagens samhälle. Ett led i detta måste vara att lägga en tyngdpunkt vid de miljöer som bildat ramen för människors arbete och vardag, d.v.s. arbetets och boendets byggnader. Därmed tydliggjordes också kulturminnesvårdens ansvar för dokumentation, vård och bevarande av industrins kulturarv.

I Värmland bildades Föreningen Värmländska Industriminnesmärken 1972, som med nyttjanderätt övertog flera industriminnen i syfte att vårda dem och att kunna underhålla dem med bidrag från AMS. En annan målsättning var att göra dem tillgängliga för allmänheten. Fler branscher utöver järn- och stålindustrin började ta ett ansvar för en dokumentation av den egna branschens utveckling. Fackföreningsrörelsen initierade en insamling och dokumentation av material som kunde belysa arbetarrörelsens historia. Studiecirkelverksamheten kring arbetet och dess historia tog fart och bedrevs med stor intensitet under några år, inte minst i kraft av Sven Lindqvists Gräv där Du står, 1978 och Gunnar Silléns Stiga vi mot ljuset, 1977. Utställningar och amatörteaterföreställningar avlöste varanda. En rad nya forskningsprojekt formulerades med målsättningen att analysera industrialismens framväxt och dess konsekvenser för människor och miljöer. Allt fler engagerades på olika sätt $i$ en dokumentation av arbetets historia.

År 1973 hölls den första internationella konferensen The First International Conference on the Conservation of Industrial Monuments (FICCIM) arrangerad av Ironbridge Gorge Museum Trust. Museet hade kommit till stånd och byggts upp under Neil Cossons ledning. Det marknadsfördes som den plats where the Industrial Revolution was born och kom under 1970- och 1980-talen att spela en stor roll för de många museer med industrihistoriska byggnader och samlingar som nu börja- 
80 de växa fram i Europa. Jag vill minnas att denna första konferens samlade ett 40-tal deltagare från 17 länder. Huvudsakligen var det ett antal antikvarier och teknikhistoriker som sysslade med traditionell kulturminnesvård eller teknikhistoria i strikt bemärkelse.

Vi som var där var i varje fall entusiastiska och hade nog alla den känslan att det var något nytt som höll på att hända. Vårt ämnesområde kändes angeläget och det var spännande att få redovisa de första ansatserna till en spirande industriminnesvård inför ett internationellt forum.

Sverige fick möjligheten att arrangera den tredje internationella konferensen, som ägde rum i Grangärde i Dalarna år 1978. Huvudarrangörer var Riksantikvarieämbetet och Nordiska museet. Denna konferens kom att få stor betydelse för det fortsatta industriminnesvårdsarbetet nationellt, men också för det internationella samarbete som därmed intensifierades.

Men industriarkeologin hade som sagt inte fătt någon given plattform varken $\mathrm{i}$ Europa eller någon annan del av världen vid den tidpunkten. Visst kunde man rapportera om framgångsrika insatser för att bevara anläggningar som representerade ett viktigt steg i den tekniska eller industriella utvecklingen. Men sådana räddningsaktioner var mer sällsynta än rapporterna om tillkortakommanden, om rivningar, om kasserade arkiv, om bristande kunskap och förståelse för teknik- och industrihistoria.

\section{EN FJÄRDE FAS - ARBETSUPPGIF- TERNA FÖRÄNDRAS}

Under 1970-talet upplevde vi hur industriarkeologernas arbetsfält förändrades och hur arbetsuppgifterna omformulerades.
Till en början accepterades begreppet Industrial Archaeology. Senare ersattes det i internationella sammanhang av The Industrial Heritage. Man ville därmed markera att ämnesområdet vidgats. I industriarkeologins barndom var det teknikhistoria i mer avgränsad bemärkelse som dominerade. Efter hand vidgades intresset till industrimiljöerna.

I mitten av 1970-talet började man tala om att bevara och dokumentera arbetarkultur i vidare bemärkelse. Ungefär samtidigt började nybyggnadsvågen, som varit så markant i flera europeiska länder, att mattas och rivningsraseriet upphörde. Återanvändning och ombyggnad vann allt större gehör. Uttjänta fabriker fick nytt innehåll och övergivna industriområden ny användning.

På samma sätt som industriminnesvårdens verksamhetsområde breddades, så flyttades även tidsgränserna. Till en början var det de historiska sammanhangen som studerades och de tidigindustriella miljöerna som ägnades uppmärksamhet. De engelska industriarkeologerna var inte ensamma om sitt intresse för industrins genombrottsår och tidiga expansionsskeden. I början av 80-talet kom samtidsdokumentationen åtminstone i Sverige och genom Nordiska museets initiativ med SAMDOK att framstå som en alltmer angelägen uppgift. Kanske är det t.o.m. viktigare för oss just nu att dokumentera det senaste omvandlingsskedet - det försvinner förmodligen snabbare än de kvarvarande historiska lämningarna. Man strävar dessutom efter att förverkliga allt aktivare bevarandeprogram och att finna nya former för musealt bevarande - hit hör de ansatser som gjorts för att i museal regi slå vakt om att gamla yrkestraditioner vid- 
makthålles och att nya arbetstillfällen skapas där människor känner främlingskap i det högteknologiska samhällets arbetsmiljöer.

Från fackligt håll framfördes önskemål om en vidgad forskning kring arbetslivets historia och större utrymme för arbetets historia i museerna. LO:s kulturombudsman Bertil Jansson framhöll på en konferens anordnad av IVA:s teknikhistoriska råd 1979 att det fanns stora luckor i museernas utställningar.

Det sägs att 'när historien kommer till museerna blir den ofarlig'. Arbetarklassens historia finns runt omkring oss - men sällan på museerna. Där saknas bilder och dokumentation av vår tids arbetsliv, vilket även innebär en begränsning av forskarnas möjligheter till kunskapsunderlag. Både museer och den byggda miljön kan ge kunskapsrelief över äldre tiders maktstrukturer och samhällsförhållanden. Men kommande generationer av arbetets män och kvinnor bör ha tillgång till ett vidgat kulturarv. Museerna bör ge hela folkets historia, liksom byggnadsminnesvården i ett dialektiskt perspektiv.

Vid denna tidpunkt hade också planerna på ett centrum för arbetets historia i Norrköping tagit form.

Under 1980-talet formulerades också ramarna för en rad ekomuseer som, i likhet med Ekomuseum Bergslagen, siktade mot ett annorlunda museikoncept än det traditionella. Samtidigt tillkom nya arbetslivsmuseer och utvecklingen var explosionsartad. Över 1.600 arbetslivsmuseer har Jan af Geijerstam registrerat i den guide över arbetslivsmuseer som inom kort skall publiceras i en andra upplaga.

Under 1990-talet har industriminnesvården fått en stark förankring i svensk kulturvård och svenskt museiväsen. Riksantikvarieämbetet har regeringens upp- drag att utarbeta ett handlingsprogram för den framtida vården av industriminnen. Ämbetet har, tillsammans med Nordiska museet, på grundval av en enkät och kontakter med länsmuseerna, kartlagt och registrerat det materiella och immateriella arvet efter industrin.

1992 bildades Industribistoriskt forum som är ett samarbetsorgan för att ur olika aspekter slå vakt om industriminnen. Genom sina medlemmar vill Industrihistoriskt forum således initiera, stödja och samordna inventering, dokumentation och forskning kring det industriella arvet liksom att finna former för att bevara och levandegöra detta arv. Genom alla aktioner som inletts under 1990-tal har industriminnesvården fått en framträdande plats i kulturmiljövården. Det förefaller som om vi står väl rustade inför ett kommande millenium. Men nya uppgifter väntar ändå ständigt bortom horisonten.

\section{SUMMARY}

The Industrial Heritage in Sweden. 100 years of activities.

Since the turn of the century 1900 attention has been paid to the Swedish Industrial Heritage. The development of activities concerned with the industrial past can be described in four phases.

The first one is characterized by the growing interest in Sweden's industrial past which occurred in the early years of the 20th Century. It was focused on the old mining and metal industry and its remains. Famous writers and artists were preoccupied with the world of the peasant ironmakers and ironworks' estates and their owners. Some of the leading industrialists within the iron and steel companies took an active interest in the preservation of the industry's cultural heritage and promoted con- 
82 servation of documents and buildings. It gave legitimacy to the subject.

The second stage is the decennium of pioneering industrial museums in Sweden: Tekniska Museet was founded in 1924 but 12 years passed before it was inaugurated in its present building. The mining museum at Falun opened in 1924 and in the same year the first decision was taken to create an industrial open-air mining museum at Ludvika. These initiatives gave birth to many others as well as to industrial company museums. Collections of old documents were brought together and documentary films on vanishing industries and working environments were made.

The third stage was the establishment and acceptancy of the cultural importance of the industrial heritage in wider circles of society, especially the national and regional conservation bodies and the labour unions. National actions were encouraged by the international development within the field and some attention is given in the article to the evolvement of Industrial Archaeology in the United Kingdom during the 1950s and 1960s.

During the fourth period we have seen how the tasks of Industrial Archaeology have been reformulated. Adaptive re-use of factories and similar buildings were taken up. Contemporary documentation was initiated by Nordiska museet. Much attention was given to the working environment and to men and women at work. The concept of the ecomuseum was accepted and gave birth to a number of museums focused mainly on the remains of the iron industry. The activities within the field of Industrial Heritage have increased during the 1990s and the Central Board of National Antiquities has been endowed with the task to present a plan for future national and regional actions and to select a number of 15 outstanding buildings and sites for future conservation. A number of institutions and organisations engaged in the conservation, documentation and research work of the Industrial Heritage have created a Forum for the Industrial
Heritage in order to promote co-operation within this field of studies.

\section{LITTERATUR}

Margareta Biörnstad, Industriminnesvård — en viktig del av kulturminnesvården och kulturpolitiken, i Daedalus 1980.

Kenneth Hudson, Industrial Archaeology - An Introduction. London 1963.

Kenneth Hudson, A Social History of Industrial Archaeology. The British Experience. London and Basingstoke 1981.

Svante Lindqvist, Tekniska Museet och bilden av Polhem, i Daedalus 1985.

Svante Lindqvist, Industrins historia - ett forskningsområde inför nya uppgifter. Referat av IVAs teknikhistoriska konferens den 15 november 1979, i Daedalus 1980.

Svante Lindqvist, An Olympic Stadium of Technology: Deutsches Museum and Sweden's Tekniska Museet, i: Brigitte Schroeder-Gudehus, Industrial Society \& its Museums 1890-1990. Paris 1990.

Marie Nisser (red.), Industriminnen. En bok om industri-och teknikhistoriska bebyggelsemiljöer. Stockholm 1979.

Marie Nisser, Vid skiljovägen. Industriminnesvården inför 1980-talet, i Daedalus 1980.

Arthur Raistrick, Industrial Archaeology. An Historical Survey. London 1972.

Göran Rosander (red.) Karl-Erik Forsslund. Författaren, folkbildaren, hembygdsvårdaren. Hedemora 1991.

Marie Nisser är professor i Industriminnesforskning vid Avdelningen for teknik- och vetenskapshistoria vid Kungl. Tekniska Högskolan i Stockholm. Adr: Avdelningen for teknik- och vetenskapshistoria, KTH, S-100 44 Stockholm.Fax +46-(0) -2462 63. 